\title{
Meningokoksemi: Aynı Coğrafyada Farklı Serotipler
}

\author{
Meningococcemia: Different Serotypes in the Same Region
}

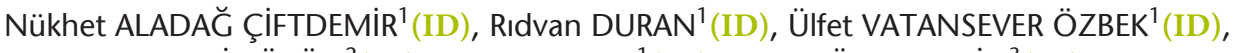

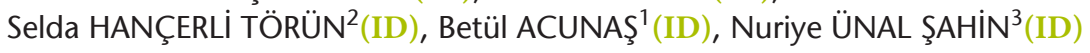 \\ 1 Trakya Üniversitesi Tıp Fakültesi, Çocuk Sağlığı ve Hastalıkları Anabilim Dalı, Edirne. \\ ${ }^{1}$ Trakya University Faculty of Medicine, Department of Pediatrics, Edirne, Turkey. \\ 2 İstanbul Üniversitesi İstanbul Tıp Fakültesi, Çocuk Sağlığı ve Hastalıkları Anabilim Dalı, Çocuk Enfeksiyon Bilim Dalı, \\ istanbul. \\ 2 Istanbul University Istanbul Faculty of Medicine, Department of Pediatrics, Division of Pediatric Infectious Diseases, \\ Istanbul, Turkey. \\ ${ }_{3}^{3}$ Sağlık Bakanlığı, Halk Sağlığı Genel Müdürlüğü, Ulusal Solunum Yolu Patojenleri Referans Laboratuvarı, Ankara. \\ ${ }^{3}$ Ministry of Health, General Directorate of Public Health, National Respiratory Pathogens Reference Laboratory, \\ Ankara, Turkey.
}

Makale Atıfı: Aladağ Çiftdemir N, Duran R, Vatansever Özbek Ü, Hançerli Törün S, Acunaş B, Ünal Şahin N. Meningokoksemi: aynı coğrafyada farklı serotipler. Mikrobiyol Bul 2020;54(1):163-170.

\section{ÖZ}

Meningokok enfeksiyonları çocukluk çağında yüksek morbidite ve mortaliteye sahip önemli bir sağlık sorunudur. Neisseria meningitidis'in 13 serogrubu vardır. Bu serogruplar arasında A, B, C, Y ve W135 en fazla invaziv hastalık yapanlardır. Serogrupların dağılımı coğrafi bölgelere ve yaş gruplarına göre değişkenlik göstermektedir. Bu raporda son yıllarda ülkemizde nadir görülen serogrup $C$ ve serogrup Y meningokoksemisi olan iki olgu sunulmuştur. Birinci olgu ateş ve bacaklardan başlayan vücuda doğru yayılan döküntü nedeniyle çocuk acil servisimize başvuran 2.5 yaşında kız hastadır. Hastanın başvurusunda genel durumunun orta, halsiz, uykuya meyilli olduğu tüm vücutta yaygın purpurik döküntülerinin olduğu görülmüştür. Hastanın döküntüsü, uykuya meyilli olması ve tansiyon düşüklüğü nedeniyle meningokoksemi düşünülmüştür. Hemen antibiyotik tedavisine başlanan ve lomber ponksiyon yapılan hastanın laboratuvar tetkiklerinde lökosit sayısı: 3600/mm³ (\%61 nötrofil), hemoglobin: $11.1 \mathrm{~g} /$ dl, trombosit sayısı: $127.000 / \mathrm{mm}^{3}$, C-reaktif protein: $10 \mathrm{mg} / \mathrm{dl}$, sedimentasyon: $6 \mathrm{~mm} / \mathrm{saat}$, biyokimya test değerleri normal, protrombin zamanı: $28.8 \mathrm{sn}$ (normal değer= 11-16 sn), protrombin aktivitesi: \%36, "International normalized ratio (Uluslararası düzeltme oranı; INR)": 2.13 (normal değer=1-1.5), aktive parsiyel tromboplastin zamanı: $57.7 \mathrm{sn}$ (normal değer= 25-35 sn), fibrinojen: $246 \mathrm{mg} / \mathrm{dl}$ (normal değer = 200-400 mg/dl), beyin omurilik sIVISI (BOS)'nda protein: $21 \mathrm{mg} / \mathrm{dl}$, glukoz: $62 \mathrm{mg} / \mathrm{dl}$ saptanmıştır. Mikroskobik incelemede sekiz adet hücre görülmüştür. Hastanın döküntüleri giderek artarak hipotansiyon gelişmiş ancak beyin omurilik sıvısı (BOS) kültüründe üreme olmamıştır. Hastada polimeraz zincir reaksiyonu (PCR) ile N.meningitidis serogrup $C$ saptanmıştır. Tedavisi devam eden hastaya altıncı gününde immün aracılı artrit gelişmesi nedeniyle nonsteroid antienflamatuvar ilaç tedavisi başlanmıştır. Antibiyotik, taze donmuş plazma ve inotrop tedavisiyle hasta düzelmiştir. íkinci olgu, ilk olgudan üç gün sonra ateş ve pansitopeni nedeniyle malignite öntanısıyla hastaneye sevk edilen 13 yaşında erkek olgudur. Hastaneye başvuru sırasında genel durumu orta, halsiz ve yüzünde birkaç adet purpurik peteşiyel döküntü olan

Iletişim (Correspondence): Dr. Öğr. Üyesi Nükhet Aladağ Çiftdemir, Trakya Üniversitesi Tıp Fakültesi, Çocuk Sağlığı ve Hastalıkları Anabilim Dalı, Edirne, Türkiye. Tel (Phone): +90 533311 3800, E-posta (E-mail): nukhetaladag@yahoo.com 
hastanın takibinde genel durumu hızla kötüleşmiştir. Kardiyak arrest olan hasta yapılan resüsitasyona yanıt vermemiştir. Hastaneye yatıııldığında yapılan tetkiklerinde lökosit sayısı: $6000 / \mathrm{mm}^{3}$ (\%79 nötrofil), hemoglobin: $17.3 \mathrm{~g} / \mathrm{dl}$, trombosit sayısı: $16.000 / \mathrm{mm}^{3}$, C-reaktif protein: $8.63 \mathrm{mg} / \mathrm{dl}$, protrombin zamanı: $92.6 \mathrm{sn}$, protrombin aktivitesi \%10, INR: 6.78 aktive, parsiyel tromboplastin zamanı: $231.5 \mathrm{sn}$ olarak belirlenmiştir. Postmortem yapılan lomber ponksiyonda alınan BOS örneğinde (protein: 95 mg/dl, glukoz $35 \mathrm{mg} / \mathrm{dl}$ ) üreme olmamış, PCR ile N.meningitidis serogrup Y saptanmıştır. Son yıllarda ülkemizde çok nadir görülen iki serotip aynı zaman diliminde aynı coğrafyada yaşayan iki farklı olguda görülmüştür. Bu olgu raporu, meningokokal hastalıkların önlenmesinde sürveyansın önemini ortaya çıkarmaktadır.

Anahtar kelimeler: Çocuk; meningokoksemi; Neisseria meningitidis; Trakya.

\section{ABSTRACT}

Meningococcal infections are important health problems causing high morbidity and mortality. Neisseria meningitidis have 13 serogroups. A, B, C, Y and W135 are the most common causes of invasive disease among those serogroups. The distribution of the serogroups differs according to the geographical regions and the age groups. In this case report, two cases of meningococcemia infected with serogroup $C$ and $\mathrm{Y}$ of $\mathrm{N}$.meningitidis rarely seen in our country were presented. First case was a two and a half year-old female patient who has admitted to our pediatric emergency unit with fever and rash spreading from lower extremities to her body. The patient had diffuse purpuric rash with generalized weakness and tendency to sleep at admission. The patient has been suspected as meningococcemia because of the skin rash, tendency to sleep and hypotension. Antibiotics treatment was started immediately and lumber puncture was performed. In blood tests, leukocyte count: $3600 / \mathrm{mm}^{3}$ (61\% neutrophils), hemoglobin: $11.1 \mathrm{~g} /$ dl, platelet count: $127.000 / \mathrm{mm}^{3}$, C-reactive protein: $10 \mathrm{mg} / \mathrm{dl}$, erythrocyte sedimentation rate: $6 \mathrm{~mm} /$ hour, prothrombin time: 28.8 seconds (normal value $=11-16$ ), prothrombin activity: $36 \%$, international normalized ratio (INR): 2.13 (normal value= 1-1.5), activated partial thromboplastin time: 57.7 seconds (normal value $=25-35 \mathrm{sec}$ ), fibrinogen: $246 \mathrm{mg} / \mathrm{dl}$ (normal value $=200-400 \mathrm{mg} / \mathrm{dl}$ ) and in cerebrospinal fluid protein: $21 \mathrm{mg} / \mathrm{dl}$ and glucose: $62 \mathrm{mg} / \mathrm{dl}$ were found. There were eight cells in the microscopic examination. Skin rashes were increased and the patient became hypotensive. No microorganisms were isolated in blood and cerebrospinal cultures. N.meningitidis serogroup $C$ was isolated from the cerebrospinal fluid of the patient using polymerase chain reaction (PCR). The patient suffered from immune-mediated arthritis in the sixth day of treatment and nonsteroidal anti-inflammatory drugs were given. The patient has recovered with antibiotics, fresh frozen plasma and inotropic treatment. Second case was a 13 year-old male patient who has admitted three days after the first case with a pre-diagnosis of malignancy because of pancytopenia and fever. The patient had generalized weakness and a few petechial purpuric rashes at the facial region at admission. After the admission general status of the patient has worsened rapidly and he has died as a result of cardiovascular arrest. Blood tests in admission showed leukocyte count: $6000 / \mathrm{mm}^{3}$ (79\% neutrophils), hemoglobin: $17.3 \mathrm{mg} / \mathrm{dl}$, platelet count: $16.000 / \mathrm{mm}^{3}$, C-reactive protein: $8.63 \mathrm{mg} / \mathrm{dl}$, prothrombin time: 92.6 seconds, prothrombin activity: 10\%, INR: 6.78, activated partial thromboplastin time: 231.5 seconds. Cerebrospinal fluid obtained from postmortem lumbar puncture showed no growth (protein: $95 \mathrm{mg} / \mathrm{dl}$, glucose: $35 \mathrm{mg} / \mathrm{dl}$ ) and N.meningitidis serogroup $\mathrm{Y}$ was detected by PCR. Two meningococcemia cases caused by two different serogroups which are rarely seen in our region in recent years were presented at the same time period in the same hospital. This case report pointed out that surveillance has a great importance in such diseases.

Keywords: Children; meningococcemia; Neisseria meningitidis; thrace.

\section{Gíriş}

Meningokok enfeksiyonları çocukluk çağında yüksek morbidite ve mortaliteye sahip önemli bir sağlık sorunudur. Neisseria meningitidis gram-negatif bir diplokok olup, 13 serogrubu vardır. Bu serogruplar arasında A, B, C, Y ve W135 en fazla invaziv hastalık 
yapanlardır. Serogrupların dağılımı coğrafi bölgelere ve yaş gruplarına göre değişkenlik göstermektedir ${ }^{1,2}$. 2005 yılından önce Türkiye'de invaziv meningokokal hastalık için epidemiyolojik çalışma ve takip yapılmamış olup, serogruplar belirlenmemiştir. Yapılmaya başlayan sürveyans ile hastalık yapan serogrupların yıllar içinde değişkenlik gösterdiği görülmektedir ${ }^{3}$. Bu çalışmada, son yıllarda ülkemizde nadir görülen serogrup $C$ ve serogrup $\mathrm{Y}$ meningokoksemisi görülen iki olgu sunulmuştur.

\section{OLGU SUNUMU}

Bu çalışma, Trakya Üniversitesi Bilimsel Araştırmalar Etik Kurulu onayı ile gerçekleştirildi (Tarih: 30/09/ 2019 ve Karar no: 16/25).

\section{Olgu 1}

İki buçuk yaşında kız hasta ateş ve bacaklardan başlayan vücuda doğru yayılan döküntü nedeniyle çocuk acil servisimize başvurdu. Ateşinin 10 saat önce başladığı ve ateş düşürücü şurup verildiği öğrenildi. Özgeçmişinde belirgin bir özellik yoktu. Hastanın başvurusunda genel durumunun orta, halsiz, uykuya meyilli olduğu tüm vücutta yaygın purpurik döküntülerinin olduğu görüldü (Resim 1). Kalp atım hızı: 100/dk, solunum sayısı: 19/dk, kan basıncı 80/40 mmHg, vücut sıcaklığı: $38^{\circ} \mathrm{C}$, Glasgow koma skoru (GKS): 15 olarak saptandı. Meningeal iritasyon bulgusu olmayan hastada döküntü, uykuya meyil ve tansiyon düşüklüğü nedeniyle meningokoksemi düşünülerek intravenöz yol açılıp serum fizyolojik verilip seftriakson başlandı. Hastaya lomber ponksiyon uygulandı. Hastanın da-

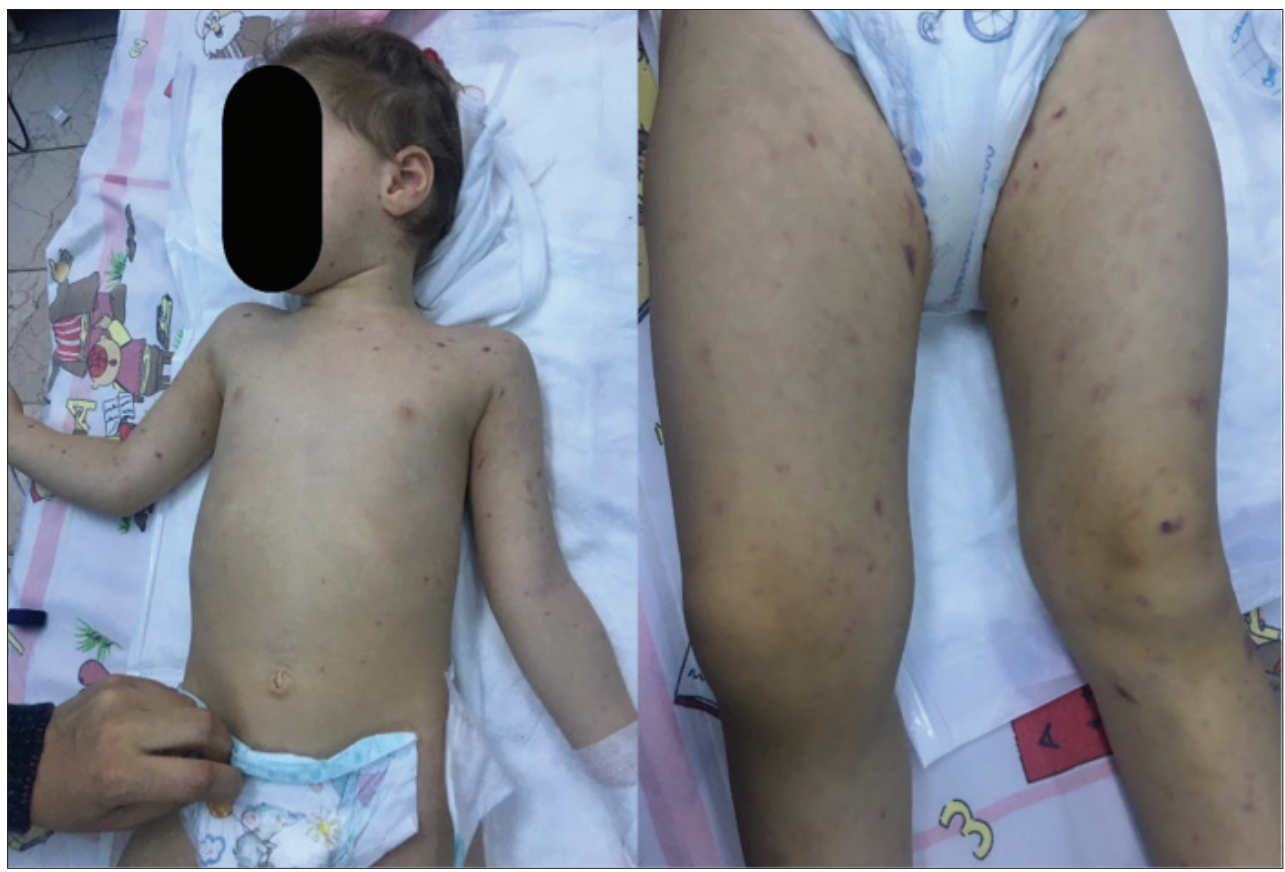

Resim 1. Birinci olgunun başvuru sırasındaki döküntüleri. 
kikalar içinde GKS ve kan basıncı değerleri düştü. Döküntüleri belirginleşerek sayıca artış gösterdi. Taze donmuş plazma ve dopamin başlanan hasta çocuk yoğun bakım servisine yatırıldı. Yapılan tetkiklerinde lökosit sayısı: 3600/mm³, hemoglobin: $11.1 \mathrm{~g} / \mathrm{dl}$, trombosit sayısı: 127.000/mm³, \%61 nötrofil, \%34 lenfosit, \%3 monosit, \%1 bazofil, \%1 eozinofil, C-reaktif protein: $10 \mathrm{mg} / \mathrm{dl}$, sedimentasyon: $6 \mathrm{~mm} / \mathrm{saat}$, biyokimya normal, protrombin zamanı: 28.8 saniye (11-16), protrombin aktivitesi: \%36, INR: 2.13 (1-1.5), aktive parsiyel tromboplastin zamanı: 57.7 saniye (normal değeri= 25-35 saniye), fibrinojen: 246 mg/dl (normal değer= 200-400 mg/dl) olarak saptandı. Beyin omurilik sıvısı (BOS) değerlendirmesinde protein: $21 \mathrm{mg} / \mathrm{dl}$, glukoz: $62 \mathrm{mg} / \mathrm{dl}$ olarak saptandı. Mikroskobik incelemede sekiz hücre görüldü. il Sağlık Müdürlüğüne bildirimi yapılarak hastanın BOS örneği laboratuvara gönderildi. Hastanın saatler içinde döküntülerinde ve inotrop ihtiyacında artış gözlendi (Resim 2). BOS kültüründe ve kan kültüründe üreme olmadı. Sağlık Bakanlığı Üst Solunum Yolu Patojenleri Referans Laboratuvarında gerçek zamanlı polimeraz zincir reaksiyonu (Rt-PCR) ile N.meningitidis pozitif bulundu ve moleküler yöntemle yapılan serogruplandırmada serogrup $C$ saptandı. Hastanın inotrop ihtiyacı üç gün sürdü. Tedavisinin altıncı gününde sol dizde ağrı ve şişlik yakınması oldu. Diz eklemine yönelik yapılan ultrasonografide sol suprapatellar bursa bölgesinin derin kısmında 5 mm'ye varan anekoik karakterde yoğun içerikli olmayan efüzyon saptandı. Sıvı miktarının az olması nedeniyle ponksiyon yapılamadı. Antienflamatuvar olarak ibuprofen tedavi başlanan hastanın şikayetleri gerileyerek yatışının 20. gününde taburcu edildi.

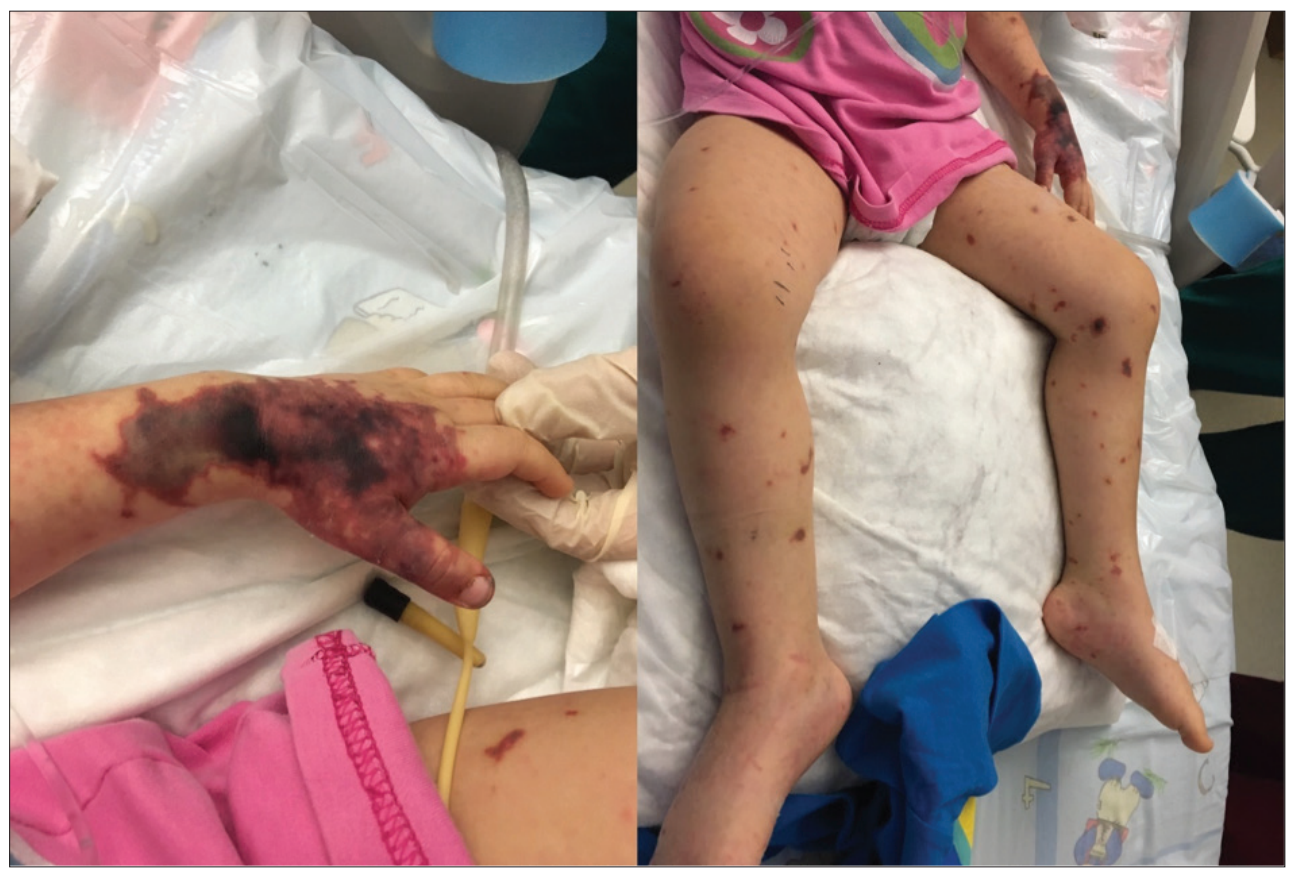

Resim 2. Birinci olgunun tedavi sırasındaki döküntüleri. 


\section{Olgu 2}

On üç yaşında erkek hasta ateş ve pansitopenisinin olması nedeniyle malignite ön tanısıyla dış merkezden hastanemize sevk edildi. Öyküsünden hastanın aynı gün ateşinin başladığı bu nedenle ilçedeki devlet hastanesine başvurduğu, ateşi düşürülerek eve gönderildiği, akşam saatlerinde tekrar ateşinin yükselmesi, halsizliğinin artması üzerine başka bir hastaneye başvurduğu ve gözlem sırasında bir kez kusması olduğu öğrenildi. Başvurduğu ikinci hastanede alınan tetkiklerinde pansitopenisi (üç kez çalışılan örneklerde lökosit sayısı: 1080/1620/1230 $\mathrm{mm}^{3}$, hemoglobin: 11.9/11.3/12.1 g/dl, trombosit sayısı: $86.000 / 72.000 / 21.000 \mathrm{~mm}^{3}$ ) saptanan hastanın özgeçmişinde bilinen bir hastalık ve devamlı kullandığı bir ilaç olmadığı öğrenildi. Hastanın geldiğinde genel durumu orta, halsiz görünümlü kalp atım hızı: 96/dk, solunum hızı: 18/dk, kan basıncı: 115/69 mmHg, $\mathrm{SpO}_{2}: \% 96$, yüzünde birkaç adet peteşiyel döküntü, orofarenks hiperemisi dışında sistem muayeneleri doğaldı. Yüzündeki döküntülerin ambulansta gelirken ortaya çıtığı öğrenildi. Damar yolu açılıp, intravenöz sıvı başlandı. Malignite açısından akciğer grafisi çekilmek üzere acil radyolojiye götürüldüğü sırada konuşamamaya başlayan hasta hemen acil servise geri alındı. Tansiyonu hızla düşen hastaya $(107 / 10 \mathrm{mmHg}$ ) serum fizyolojik yüklendi. Solunumu duran ve kalp atımları azalan hastaya resüsitasyon başlandı. Alnında ve dudak çevresinde birkaç adet basmakla solmayan peteşiyal döküntüsü olan, hızla kötüleşen hastaya olası meningokoksemi tanısıyla intravenöz seftriakson yapıldı. İntraosseöz damar yolu açılarak dopamin ve noradrenalin başlandı. Resüsitasyona yanıt vermeyen hasta kaybedildi. Hastaneye başvurusunda yapılan tetkiklerinde lökosit sayısı: 6000/mm³, hemoglobin $17.3 \mathrm{~g} / \mathrm{dl}$, trombosit sayısı: 16.000/mm³, \%79 nötrofil, \%19 lenfosit, \%1 monosit, \%1 eozinofil, C-reaktif protein: $8.63 \mathrm{mg} / \mathrm{dl}$, protrombin zamanı: 92.6 saniye (normal değer= 11-16 saniye), protrombin aktivitesi \%10, "international normalized ratio (uluslararası düzeltme oranı; INR)": 6.78, aktive parsiyel tromboplastin zamanı: 231.5 saniye (normal değer= 25-35 saniye) olarak belirlendi. Postmortem lomber ponksiyon ve kemik iliği aspirasyonu yapıldı. BOS biyokimyasında protein: 95 mg/dl, glukoz: 35 $\mathrm{mg} / \mathrm{dl}$ olarak saptandı. BOS kültüründe üreme olmayan hastanın kemik iliği aspirasyonu incelemesinde hiperselüler kemik iliği, her seri kesintisiz devam eden megakaryositleri mevcut olup blast sayısı < \%5 olarak değerlendirildi. Kan kültüründe üreme olmayan hasta meningokoksemi ön tanısı ile İ Sağlık Müdürlüğüne bildirimi yapılarak BOS örneği laboratuvara gönderildi. Sağlık Bakanlığı Üst Solunum Yolu Patojenleri Referans Laboratuvarında incelenen örnek Rt-PCR ile N.meningitidis pozitif bulundu ve moleküler yöntemle yapılan serogruplandırmada N.meningitidis serogrup Y olarak saptandı.

\section{TARTIŞMA}

Meningokok enfeksiyonlarında tek rezervuar insan olup enfeksiyon yakın temas ve damlacık yoluyla bulaşmaktadır. Hastalık en sık kış mevsiminin son dönemleri ile ilkbahar aylarında görülmektedir ${ }^{4}$. Bu raporda sunulan iki olgu da Ocak 2019 tarihinde üç gün ara ile takip edilmiştir. Birinci olgu Edirne Merkez'de, diğerinin Tekirdağ'ın bir ilçesinde ikamet etmekte olduğu tespit edilmiştir. Meningokokal hastalık riski en sık beş yaş altı küçük 
çocuklarda olup, ikinci zirve adölesan dönemde görülmektedir. Olgularımızın yaşları bu dönemlerle uyumlu bulunmuştur. Meningokok enfeksiyonlarında; aktif veya pasif sigara içiciliği, kalabalık ev halkı, yurt gibi kalabalık yerlerde yaşamak, öpüşmek, çok partnerli olmak, insan immün yetmezlik virüsü (HIV) enfeksiyonu, aspleni, orak hücreli anemi, geç kompleman eksikliği gibi bazı immün yetmezliklerin olması risk faktörü olarak belirlenmiştir ${ }^{2,5}$. Meningokoksemi ateş ve üst solunum yolu bulguları gibi özgül olmayan prodromal dönemi takiben saatler içerisinde hızla ilerlemektedir. Olguların \%28-77'sinde başvuru sırasında hemorajik deri döküntüleri saptanmaktadır. Eşlik edebilen diğer bulgular kusma, bilinç bulanıklığı, ishal, miyalji, huzursuzluk, baş ağrısı, iştahsızlık ve tiz sesle ağlamadır $^{1,2}$. Her iki olgumuzda da başlangıç semptomu ateş ve halsizlik olarak gözlenmiştir. İkinci olgumuzda kusma klinik tabloya eklenmiştir. BOS incelemesi, menenjit tanısında çok önemli olup patojenin saptanmasında altın standart yöntemdir. Lökosit sayısı, Gram boyama, glukoz ve protein seviyeleri menenjiti doğrulamak için önemlidir. Gram boyama hızlı ve kullanışı bir yöntemdir ${ }^{1,2,6}$. BOS kültürleri bakteriyel menenjitli hastaların \%60-90'ında pozitif saptanmaktadır. Ancak, hasta lomber ponksiyon öncesi antibiyotik almışsa bu oran \%10-20'ye düşmektedir ${ }^{7}$. BOS kültürü negatif olan hastalarda PCR duyarlılık ve özgüllüğü yüksek olan tanı testidir ${ }^{8}$. Olgularımızda BOS kültüründe üreme olmamasına rağmen, PCR ile etkenin saptanması mümkün olmuştur.

Meningokoksemide hızlı tanı konularak hemen ardından antibakteriyel tedavinin başlanması sağkalım oranını etkilemektedir. Antibiyotik tedavisi hastalığın ciddiyeti ile ilişkilendirilmiş (şok, çoklu organ yetmezliği, intrakraniyal basınç artışı, ölüm dahil) artmış plazma endotoksin seviyelerinin hızla azalmasına sebep olmaktadır. Hastaların sadece üçte biri klasik menenjit bulguları (baş ağrısı, meningeal iritasyon bulguları, fotofobi, bilinç durumu değişikliği vb.) ile hastaneye başvurmaktadır. Çoğu hasta özgül olmayan bulgularla geldiği için tanı gecikmektedir ${ }^{9}$. Olgularımızdan biri de döküntü olmadan yine özgül olmayan bulgular olması nedeniyle daha önce başvurduğu iki merkezde tanı almamış ve hastanemize başvurduktan kısa süre sonra kaybedilmiştir.

Artrit komplikasyonları invaziv meningokokal hastalık seyrinde \%2-10 oranında görülür ${ }^{10}$. Meningokokal hastalığa ikincil artritler septik ve/veya immün aracılı olarak gelişebilir. Septik artrit, N.meningitidis'in direkt eklem sıvısından izolasyonu ya da kanıtlanmış başka bir yerdeki enfeksiyon sırasında artrit gelişmesi şeklindedir. İmmün aracılı artrit eklem sıvısında etken izole edilmeden meningokokal hastalıktan sonra artrit görülmesi şeklindeki tablodur ${ }^{11}$. Septik artrit meningokokal hastalığın başlangıcında görülür ve antibakteriyel tedaviye iyi yanıt verirken immün aracılı artrit hastalığın veya antibakteriyel tedavinin 4-10. günlerinde gelişir ${ }^{12,13}$. Patofizyolojisi çok net olmayıp oluşan immün komplekslerin eklem, perikard gibi dokulara gidip burada immün aracılı artrit ve perikardite neden olduğu düşünülmektedir ${ }^{10}$. Birinci olgumuzda da eklem şikayetlerinin tedavinin altıncı gününde başlaması, nonsteroid antienflamatuvarlarla iki hafta içinde düzelmesi nedeniyle immün aracılı artrit geliştiğini düşündük. 
Mevcut konjuge aşıların [Haemophilus influenzae tip B (Hib), Streptococcus pneumoniae ve N.meningitidis] kullanımı ile bakteriyel menenjitin etyolojik sebepleri büyük ölçüde değişmiştir ${ }^{3,4}$. Hib ve S.pneumoniae'ya karşı konjuge aşılar Ulusal Aşı Takvimimize girdikten sonra Hib kaynaklı menenjit olgusu 2012 yılından itibaren görülmemekte, S.pneumoniae kaynaklı menenjit olgusu ise oldukça azalmış olup, N.meningitidis önde gelen etken olarak karşımıza çıkmaktadır. Ülkemizde 1974-2012 yılları arasındaki tüm invaziv meningokokal olguların biraraya getirildiği derlemede serogrup B ve W135 en yaygın serogruplar olarak belirlenirken, bunları serogrup A ve C'nin izlediği belirtilmiştir. 2000'li yıllardan itibaren serogrup C'de belirgin azalma ve serogrup W135'te artış görülmektedir. Serogrup W135'teki artış hac ibadetine bağlanmaktadır³. Toprak ve arkadaşlarının 2006-2009 yılları arasında PCR tabanlı sürveyans çalışmasında ${ }^{14}$ serogrup B'nin invaziv meningokokal hastalıkta en yaygın tip olduğu bildirilmiştir. Ceyhan ve arkadaşlarının 2005-2012 yılları arasındaki menenjit etkenlerini değerlendirdikleri çok merkezli çalışmalarında ${ }^{15}$, N.meningitidis serogrup C etken olarak hiç saptanmazken serogrup Y 3 (\%0.9) olguda belirlenmiştir. 2013-2014 yıllarında meningokokal menenjit etkenlerinin incelendiği diğer bir çalışmada serogrup B sıklığı \%32.9, serogrup W135 \%42.4, serogrup A \%3.5, serogrup $Y \% 2.4$ olarak bildirilmiş, serogrup $C$ hiç saptanmamıştır ${ }^{16}$. Bu çalışmadaki iki olguda son yıllarda Türkiye'de çok nadir görülen tipler olan serogrup $\mathrm{Y}$ ve $\mathrm{C}$ belirlenmiştir. Avrupa Hastalık Önleme Merkezinin yıllık sürveyans verilerine göre 2017 yılında 1521 (\%51) serogrup B olgusu, 485 (\%16) serogrup C olgusu, 345 (\%12) serogrup Y olgusu tespit edilmiştir. Olguların mortalite hızı ise, serogrup $C^{\prime}$ de \%15, serogrup $Y^{\prime}$ de \%8, serogrup $B^{\prime}$ de $\% 7$ olarak saptanmıştır ${ }^{17}$. Edirne ili ve çevresi bulaşıcı hastalıkların sürveyansında Avrupa bölgesinden gelen insan hareketliliği göz önüne alındığında önemli bir merkezdir. Meningokoksemi serotipinin coğrafya ve yaşa bağlı olarak değişkenlik göstermesi nedeniyle, koruyucu aşı politikalarının belirlenmesinde tüm bu dinamiklerin göz önüne alınması gerekmektedir. Diğer yandan, aşı ile önlenebilir hastalıkların sürveyansının yapılması çok önemlidir. Yıllar içinde etkenlerin sıklığı ve tipleri değişebilmektedir ${ }^{16}$. Aşı ile önlenebilir bir enfeksiyon olan N.meningitidis'e karşı geliştirilmiş aşılar mevcut olup, bunlar ülkemizde Sağlık Bakanlığı tarafından onay almış durumdadır. Meningokok aşıının tüm çocuklara uygulanabilmesi amacıyla aşının Ulusal Aşı Programına alınması uygun olacaktır.

\section{ÇIKAR ÇATIŞMASI}

Yazarlar bu makale ile ilgili herhangi bir çıkar çatışması bildirmemişlerdir.

\section{KAYNAKLAR}

1. Pollard AJ, Sadarangani M. Neisseria meningitidis (meningococcus), pp: 1356-65. In: Kliegman RM, Stanton BF, St Geme JW, Schor NF (eds). Nelson Textbook of Pediatrics 2016, 20th ed, Elsevier, Philadelphia.

2. Salman N, Sütçü M. Meningokok enfeksiyonları, pp: 381-5. In: Nuran Salman, Ayper Somer, Işık Yalçın (eds). Çocuk Enfeksiyon Hastalıkları. 2015, 2. Baskı, Akademi Yayınevi, İstanbul.

3. Bakır M, Altınel S. Review of invaziv meningococcal disease during the last 40 years in Turkey. Expert Rev Vaccines 2015;14(8):1089-97. 
4. Hançerli Törün S, Salman N. İnvaziv meningokok hastalığı ve aşıları. Çocuk Dergisi 2013;13(1):1-5.

5. Lundbo LF, Benfield T. Risk factors for community-acquired bacterial meningitis. Infect Dis (Lond) 2017;49(6):433-44.

6. Swanson D. Meningitis. Pediatr Rev 2015;36(12):514-24.

7. Van de Beek D, Cabellos C, Dzupova O, Esposito S, Klein M, Kloek AT et al.; ESCMID Study Group for Infections of the Brain (ESGIB). ESCMID guideline: diagnosis and treatment of acute bacterial meningitis. Clin Microbiol Infect 2016;22(Suppl 3):S37-62.

8. Brouwer MC, Thwaites GE, Tunkel AR, Van de Beek D. Dilemmas in the diagnosis of acute community-acquired bacterial meningitis. Lancet 2012;380(9854):1684-92.

9. Nadel S. Treatment of meningococcal disease. J Adolesc Health 2016;59(Suppl 2):S21-8.

10. Goedvolk CA, Von Rosenstiel IA, Bos AP. Immune complex associated complications in the subacute phase of meningococcal disease: incidence and literature review. Arch Dis Childhood 2003;88:927-30.

11. Schaad UB. Arthritis in disease due to Neisseria meningitidis. Rev Infect Dis 1980;2(6):880-8.

12. Masson-Behar V, Jacquier H, Richette $P$, Ziza JM, Zeller V, Rioux C, et al. Arthritis secondary to meningococcal disease: a case series of 7 patients. Medicine (Baltimore) 2017;96(29):e7573.

13. Cabellos C, Nolla JM, Verdaguer R, Pelegrin I, Ribera A, Ariza J, et al. Arthritis related to systemic meningococcal disease: 34 years' experience. Eur J Clin Microbiol Infect Dis 2012;31(10):2661-6.

14. Toprak D, Soysal A, Torunoglu MA, Turgut M, Türkoğlu S, Pimenta FC, et al. Turkish Meningitis Study Group. PCR-based national bacterial meningitis surveillance in Turkey: years 2006 to 2009. Pediatr Infect Dis J 2014;33(10):1087-9.

15. Ceyhan M, Gurler N, Ozsurekci Y, Keser M, Aycan AE, Gurbuz V, et al. Meningitis caused by Neisseria meningitidis, H.influenzae type B and Streptococcus pneumoniae during 2005-2012 in Turkey: a multicenter prospective surveillance study. Hum Vaccin Immunother 2014;10(9):2706-12.

16. Ceyhan M, Ozsurekci Y, Gürler N, Karadag Oncel E, Camcioglu Y, Salman N, et al. Bacterial agents causing meningitis during 2013-2014 in Turkey: a multi-center hospital-based prospective surveillance study. Hum Vaccin Immunother 2016;12(11):2940-5.

17. Publication series: Annual Epidemiological Report on Communicable Diseases in Europe; Invasive meningococcal disease - Annual Epidemiological Report for 2017 https://ecdc.europa.eu/sites/portal/files/ documents/AER_for_2017-invasive-meningococcal-disease.pdf (erişim tarihi: 26.08.2019). 